\title{
Survival of the Misfittest - Stakeholder Enactment as Performance Buffer for Contingency Misfits
}

\author{
Michael Pirson \\ Fordham University \\ Dongli Zhang \\ Fordham University
}

This study explores how contingency misfit can possibly be compensated. The paper particularly focuses on stakeholder enactment as a dynamic adaptation mechanism to overcome configurational misfit. By analyzing data from 238 firms located in eight countries, our study shows that stakeholder enactment can indeed buffer for contingency misfit. Enactment of internal stakeholders buffers the structure-strategy misfit, while enactment of external stakeholders buffers both the environment-organization misfit and structure-strategy misfit.

\section{INTRODUCTION}

Scholarly research streams in the strategic management literature have time and again confirmed the relevance of configurational fit for performance (Burton and Obel, 2004; Haakonsson, et al., 2008; Ketchen, et al., 1997). Several forms of configurational fit, such as environment-organization fit as well as internal fit between e.g. strategy and structure have been widely studied and found to affect organizational success. However, recent research suggests that configurational misfits between environmental uncertainty, strategy and structure are only affecting performance to a certain degree (Burton, et al., 2002). Further studies show that when configurational fit matters is unclear and that misfits could be buffered. As a consequence, research has been trying to uncover the buffering elements for misfit configurations. This study is equally trying to explore how contingency misfit can possibly be compensated. We particularly focus on stakeholder enactment as a dynamic adaptation mechanism to overcome configurational misfit.

Based on early findings that organic firm structures outperform rigid hierarchies when environmental conditions are uncertain (Burns and Stalker, 1961), contingency theorists argued that certain configurational setups outperform others given different environmental conditions. Lawrence and Lorsch (1967), for example, found that in certain manufacturing industries, e.g. plastics, fit between structure and environment explains performance outcomes. Gresov (1989) showed that a deviance from such fit proposition indeed decreases performance outcomes and concluded that organic design performs in a superior manner in uncertain environments. Similarly, Naman and Slevin (1993) studied 82 manufacturing firms and found that fit positively affects performance. Doty, Glick, and Huber (1993) suggested that particular configurational fits between strategy, structure and environment as proposed by 
Miles, Snow, Meyer, and Coleman (1978) lead to improved performance across various industries. Lee and Miller (1996) explored firm performance in the context of Korea as it transitioned from a closed to more globalized economy and supported that those firms with strategy-environment fit outperformed those lacking of such kind of fit. Zajac, Kraatz, and Bresser (2000) examined such findings in the context of the service industry, particularly banking, and found that dynamic perspective of fit with environmental changes also predicts performance outcomes. Studying savings and loan institutions, they found that contingency misfits between environment, structure and strategy directly affected bank's performance negatively. Burton, Lauridsen, and Obel (2002) explored a multi-contingency model and suggested that both situational and contingency misfits or a combination thereof lead to decreased performance in small and medium-sized Danish firms. Payne (2006) examined organizations in the medical industry and concludes that despite several potentially equifinal configurational fit options, deviance still incurs a misfit penalty. These findings have led to an overall assumption that misfit is a condition that should be temporary and management should move organization back to fit to increase performance (Donaldson, 2001).

As the field and empirical testing developed the direct connection between certain configurations and performance was questioned, however, while some found support for fit to matter, scholars found a variety of configurations that provided similar outcomes, described as equifinal. Gresov and Drazin (1997) for example find that structural misfits per se did not affect performance, rather that different structural setups were yielding similar viability. Doty et al. (1993) found that Mintzberg's configurational types had no performance implication across various industries studied. Miller (1992) found no significant relationships between external fit and financial performance of small businesses studied in Quebec, Canada. He suggests that such lack of external fit can be compensated by better internal fit, especially in smaller firms. In general, he suggests that contingency fit imperatives in practice are difficult to achieve, as environment- organization fit requirements are often inconsistent with internal fit requirements (structure, strategy, process). Miller (2006) found that sequential adaptation may have better performance implications than direct fit achievement.

In addition to whether specific configurational setups and fit matter at all, the amount to which fit and performance were connected was also questioned. Burton Lauridesen and Obel (2002) find that while overall fit and alignment is helpful for organizational performance, additional misfits (situational/contingency) did not affect performance. Other scholars similarly find equifinal configurations so that the predictive value of traditional contingency theory research is challenged (Galunic and Eisenhardt, 1994; Gresov and Drazin, 1997).

In this paper we wish to draw on the richness of contingency theory and configurational perspectives and connect them through loose coupling theory to explore potential reasons why results regarding fit and misfit are unclear. While a majority of scholars argues that fit is what management should work towards (Donaldson, 2001), we wish to find out particularly why accumulated misfit does not incur the predicted performance reductions. We specifically will examine the role of emergent configurational setups that are supported by stakeholder relationships (stakeholder enactment) outside of the specter of planned and structured organizational design. We do so by employing three separate yet connected theoretical perspectives, contingency theory, configurational perspectives, loose coupling and stakeholder management.

\section{THEORETICAL BACKGROUND}

While scholars for some time suggested moving away from simplistic perspectives on fit, they have not abandoned the search for performance related organizational design questions. In fact, Van de Ven and colleagues (2013) strongly argue to revive and revisit the notion of configurational design questions. In addition other scholars suggest to examine reasons for equifinality more closely and also understand mechanisms that allow organizations to remain viable despite configurational misalignment (Wiklund and Shepherd, 2005). Burton and Obel (1998), for example, hint at the relevance of organizational climate and managerial style as ways of re-achieving fit. Perez-Nortvedt, Payne, Short, and Kedia (2008) suggest 
entrainment as a conceptual mechanism to explain how realignment of temporal misfit can be achieved, Daneels (2008) suggests enactment as a mechanism to compensate for configurational misfits allowing loosely coupled entities to achieve tighter alignment.

Despite such suggestions the area of configurational design and explanations have been neglected in the recent past. So that scholars feel the need to urge for a renewed examination of the reasons and mechanisms underlying such unclarity. Given the renewed call for studies of organizational design and the mechanisms underlying performant organizing, we explore in this paper reasons for such unclarity in configurational results by examining potential buffers.

To do so, we rely on three interlinking conceptual perspectives, which we introduce in turn: Configuration and contingency theory, tight and loose coupling, as well as stakeholder management.

\section{Buffering and Dynamic Adaptation- Three Theoretical Lenses}

\section{Contingency and Configurational Perspectives}

As Van de Ven, Ganco, and Hinings (2013, p. 394) argue, more scholars should "return to the frontier of organization science by reopening the study of contingency theory of organizational and institutional designs." They suggest the following reasons: 1) the critical role of design is increasingly appreciated in theory and practice, 2) new complexity and dynamism require more solid and robust theorizing, and 3) that design includes not only the focus on structure but also broader social, economic and political processes and routines (2013, p. 394). Van de Ven et al. (2013) suggest that contingency theory provides a rich theoretical foundation which has informed contemporary theories on institutional design and change (2013, p. 395).

While traditional contingency theory has been criticized for being too static in its assumptions, configurational theories have tried to adopt a perspective on dynamic elements of emergence of structure. As Meyer, Tsui, and Hinings (1993) suggest contingency theory is trying to explain "how order is designed into the parts of an organization" (Meyer, et al., 1993); (Planned coupling) configurational theorists try to explain how order emerges from interaction of these parts. Social systems are viewed as tightly coupled amalgams entangled in bidirectional causal loops" (Meyer, et al., 1993). Configurational theorists expect organizations to alternate between disequilibrium and equilibrium with discontinuous change punctuating periods of stability, change is seen as episodic in part because organizations are tightly coupled. They thus suggest that scholars focus on appropriate context embedded in appropriate patterns of coherent organizational processes and structures as well as dynamic adaptation mechanisms.

As a result of the debate between contingency and configuration scholars Van de Ven et al. (2013, p. 397) suggest that scholars should focus on the fact that organizational designs are both planned (as designs implies) and emergent (often overlooked). Planned elements of design are a form of coupling the organization with its environment as well as internal structure and strategy (Danneels, 2003). Drawing on contingency theory, scholars view the planned elements of organizational design in forms of structure and fit between organization and environment as well as internal match between structure, process and strategy (Wright and Snell, 1998). Nadler and Tushman define congruence or fit as "the degree to which the needs, demands, goals, objectives and or structure of one component are consistent with the needs, demands, goals, objectives and/or structure of another component (1980, p. 40). Inherent in most treatments of fit is the premise that organizations are more efficient and or/effective when they achieve fit relate to when a lack of fit exists (Baird and Meshoulam, 1988; Nadler and Tushman, 1988). Fit as viewed through the lens of contingency theory can be the expression of planned coupling mechanisms.

Emergent elements of organizational design can be considered relational feedback loops allowing flexibility. These emerging patterns of organizing transcend the typical contingency perspective and embrace the configurational perspective. Scholars view the emergent aspects of organizational design as an outcome of flexibility (Wright and Snell, 1998). Sanchez defines flexibility as "a firm's abilities to respond to various demands from dynamic competitive environments (1995, p. 138). Flexibility provides organization with the ability to modify current practices in response to nontransient changes in the environment. Weick (1979) argues that flexibility requires firms to detect changes in the environment and to retain a sufficient pool of novel actions so that these changes can be accommodated. (High flexibility 
firms. Absorptive capabilities ambidexterity etc.) According to Weick, such flexibility can be the result of loose coupling. Such flexibility can be the manifestation of emergent coupling mechanisms that allow a firm to respond in a dynamic environment.

In this paper we examine emergent patterns of organizing that can be the basis for dynamic adaptation and misfit buffering of contingency misfits. These patterns may provide insight into why and how equifinality can be achieved and in what ways coupling mechanisms of different sorts can be configured to achieve superior outcomes despite contingency misfit.

\section{Loose Coupling, Enactment and Entrainment and Fit}

Responding to the challenge of organizational design we argue that loose coupling perspectives can bridge planned and emerging aspects of organizational configuration. As Orton and Weick (1990) write, organizations appear to be both planned, "determinate, closed systems searching for certainty and indeterminate, open systems expecting uncertainty." Loose coupling perspectives suggest that rather than having planned and emergent aspects neatly separated, any location in an organization can contain interdependent elements that vary in the number and strength of their interdependencies. The fact that these elements are linked and preserve some degree of determinacy is captured by the word coupled in the phrase loosely coupled. Thus loose coupling allows theorists to posit that any system in any location can act on both a technical level, which is closed to outside forces (coupling produces stability) and an institutional level, which is open to outside forces (looseness produced flexibility). Beekun and Glick (2001) argue that coupling elements refer to anything that may be tied together and have a broad range: performance indicators may be coupled with decisions or goals, actors coupled with actors subunits with subunits and systems coupled with systems (2001, p. 229). Similarly they suggest that coupling domains can be placed on a continuum ranging from formal structure to informal structural depending on the content of the activity linking coupling elements, e.g. Environment, structure, structure and strategy. In the context of configurational and contingency perspectives, coupling represents the search for a structural fit mechanism and loosening is represented by the quest to remain flexible and adaptive.

Loose coupling is helpful in studying contingency misfit buffers as this perspective allows for an integrative view of planned and emergent aspects of organizational configuration. Loose coupling also provides an avenue for the study of flexibility in that it emphasizes relational patterns (Beekun, 2001, p. 227). Characteristics of loose coupling capture some important and underexplored features of multidimensional fit and interdependence in organization. According to Beekun and Glick (2001) loose coupling is relevant for organizational research as it allows us to capture the systematic patterns of interaction (Weick, 1985). Organization and environment and the existing equifinality of configurational setups suggest that O-E is more loosely coupled than theoretically suggested. Specifically the small size of performance differentials as well as the inconsistent direction of such effects points to looser rather than tighter patterns of systematic interaction.

Loose coupling theories have therefore been applied in the study of dynamic adjustment. PérezNordtvedt et al. (2008) suggest that in case of organizational environment misfit organizational leadership can decide to entrain or enact temporal fit. In case of entrainment, strategic adjustments are required to achieve structural flexibility supportive of managing the intrinsic unpredictability of events (Eisenhardt \& Brown, 1998). Other scholars suggest that entrainment is a reactive adjustment to manage organizational fit. They use the perspective on entrainment to explain temporal and dynamic adjustment of organizational fit and performance. Pérez-Nordtvedt et al. (2008) suggest that organizational environment fit will be achieved only temporally and that entrainment, the synchronization of the tempo and phase of several activities within a system explains such dynamic adjustment.

In case of enactment organizations are actively constructing their environment rather than simply adapting to it. For example, Walmart is said to have historically enacted its suppliers to provide faster product delivery, whereas fashion retailers enacting with customers to speed up product development according to changes in consumer preferences. For example, Danneels (2003) suggest that forms of enactment are allowing companies in the fashion industry to adjust to changing demands of the environment. He suggests that organizational linkages and weak ties can be the basis for organizational 
adaptation via feedback loops and proposes that performance can be enhanced via such loose coupling mechanisms.

Loose coupling perspective allows us to explain dynamic adjustment based on entrainment or enactment of stakeholder involvement. Such stakeholder management is a foundational yet emergent pattern of organizing and could be explored as the basis for dynamic adaptation or buffering of contingency misfit. Loose coupling perspectives on the interaction between purposeful planning of fit as well as the emergence of relational patterns may provide insight into why and how equifinality can be achieved. Similarly, it can provide a basis to explore in what ways coupling mechanisms of different sorts can be configured to achieve superior outcomes.

\section{Stakeholder Management and Organizational Enactment}

Loose coupling can serve as the basic logic why organizations can achieve performance levels unpredicted by static perspectives of organizational design. Stakeholder engagement as studied by Daneels (2003) can be described as an emerging configurational pattern of loose coupling that allows an organization to achieve performance. We suggest that more generally, active stakeholder engagement, internally as well as externally, could be considered enactment and may provide insight into contingency misfit buffering.

A rich literature on stakeholder management reveals its various normative, managerial and instrumental benefits. While much has been written about how to manage stakeholders (Freeman, 2010; Wicks, et al. 1999; Freeman, et al. 2004), we employ stakeholder theory as the basis for enacting loosely coupled systems. We argue that loose coupling and its enactment may be a helpful perspective to understand stakeholder management from a contingency and configurational perspective leading to fit and performance.

Managing stakeholders requires engagement with various audiences that are connected through the organization yet frequently independent of each other (loose). Stakeholders are all those that "without whose participation the organization will cease to exist (Freeman, 2010)." That includes direct stakeholders such as shareholders, employees as well as customers and suppliers, but also indirect stakeholders such as NGO's, the media or society at large. We will use stakeholder theory to argue that alignment creation of stakeholder interests that can be supported through organizational configuration 1) structure and strategy internally and 2) structure and environmental complexity externally. Using loose coupling perspectives on stakeholder enactment that allow for feedback loops, we posit that emergent aspects of organizational design can support the achievement of fit, but even more so to buffer contingency misfit.

\section{Hypotheses Development}

We use loose coupling theorizing to understand dynamic adaptation mechanisms that buffer contingency misfits. We borrow the notion of enactment as a form to establish feedback loops to conceptualize the way a firm loosely couples with 1) its external environment and 2) its internal environment. We therefore focus on enactment with 1) external stakeholders such as customers and suppliers, as well as 2) internal stakeholders such as employees. We argue that organizations and their managers may be able to overcome contingency misfits and their performance related downsides, in part, by purposefully enacting stakeholders, i.e. establishing, recognizing and utilizing feedback loops.

Building on existing configurational scholarship, we argue that firms achieving prescriptions of internal and external fit will outperform those with contingency misfits. As such, stakeholder enactment as a form of engagement between the firm and its customers and suppliers may not yield any additional performance benefits. In the case of environment and organizational structure fit, information flows would be coupled tighter so that additional information necessary to improve performance gathered by loose coupling with customers and suppliers would only be marginally beneficial. In a very similar manner, additional informational benefits provided through employee enactment would be marginal given internal fit between organizational strategy and organizational structure. Consequently we argue that given external and internal contingency fit, a firm will not perform better when enacting stakeholders, or: 
Hypothesis 1: When firms show no contingency misfit, enactment of external and internal stakeholders will not significantly influence performance.

On the contrary, we argue that when firms operate under conditions of external contingency misfit (i.e. high environmental uncertainty and strong hierarchical organizational structure), stakeholder enactment can help firms overcome negative performance outcomes. Enacting customers or suppliers a firm can establish much needed feedback loops to adjust performance related practices, without having the structural support. For example, in highly uncertain environments such as in consumer technology information barriers stemming from strong organizational hierarchies can be overcome if the firm has established channels with customers. As such, we argue that negative performance due to external contingency misfits between the environment and the organization can be compensated by the enactment of external stakeholders, or:

Hypothesis 2: Environment-organization misfit of firms can be buffered by enactment of external stakeholders.

In a similar manner, we argue that negative performance due to internal contingency misfits can be compensated by the enactment of internal stakeholders. For example, if organizational strategy directs the firm to compete via differentiation and organizational structure is highly hierarchical enactment of employees can help the firm and its managers to listen to ideas and promote creativity. On the other hand if a firm pursues a low-cost strategy and its structure is more flexible much time needs to be spent on negotiating internal tasks rather than following hierarchically supported routines. If enactment with stakeholders exists, employees could more easily provide feedback to managers and routines could be established quickly buffering negative performance outcomes. As a consequence we argue that internal contingency misfits e.g. between organizational structure and strategy can be compensated by internal stakeholder enactment of employees, or:

Hypothesis 3: Structure-Strategy misfit of firms can be buffered by enactment of internal stakeholders.

\section{METHOD}

\section{Sample and Data}

The data used in this study were obtained from the High Performance Manufacturing (HPM) project a comprehensive dataset collected by a team of international scholars in the field of operations management. The dataset included 238 manufacturing plants located in eight countries: Austria, Finland, Germany, Italy, Japan, Korea, Sweden, and the United States and three different industries: automobile suppliers, electronics, and machinery. The response rate of the HPM project was $65 \%$, which ensures a representative sample. The dataset includes only one plant per firm in the sample, which helps to maximize the independence of units in the study. Multiple respondents and the using of both subjective and objective measurement methods help reduce problems with common method bias. The distribution of the sample across countries and industries is given in TABLE 1. 
TABLE 1

SAMPLE DISTRIBUTION

\begin{tabular}{|llrrrl|}
\hline & & \multicolumn{3}{c|}{ Industry } \\
\cline { 2 - 6 } & Auto Suppliers & Electronics & Machinery & Total \\
\hline \multirow{5}{*}{ Austria } & 4 & 10 & 7 & 21 \\
\cline { 2 - 6 } & Finland & 10 & 14 & 6 & 30 \\
\cline { 2 - 6 } & Germany & 19 & 9 & 13 & 41 \\
\cline { 2 - 6 } Country & Italy & 7 & 10 & 10 & 27 \\
\cline { 2 - 6 } & Japan & 13 & 10 & 12 & 35 \\
\cline { 2 - 6 } & Korea & 11 & 7 & 10 & 31 \\
\cline { 2 - 6 } & Sweden & 7 & 9 & 11 & 24 \\
\cline { 2 - 6 } & USA & 9 & 79 & 79 & 238 \\
\hline
\end{tabular}

\section{Constructs Measurement}

Enactment of External and Internal Stakeholders

Enactment of internal stakeholders is measured by the items related to employee enactment, from the perspective of the internal stakeholder. The items survey the perceived level of communication and informational feedback loops such as: We are encouraged to make suggestions for improving performance at this plant (see APPENDIX A for all items).

Enactment of external stakeholders is measured by items related to enactment of suppliers and customers from the perspective of the firm. The items assess the perceived level of communication and informational feedback loops related to performance relevant processes, such as: We frequently are in close contact with our customers (see APPENDIX A).

Exploratory factor analysis was conducted on the three constructs to check the convergent and discriminant validity of the scales. Within each factor, the loadings, eigenvalues, and percent of variance explained were all examined to assess the convergent validity of the items which indicates the extent to which multiple measures of the same construct are in agreement (Bagozzi, et al., 1991). The results showed that all the items were loaded to the factor that they were supposed to load to. Confirmative factor analysis (CFA) was then used to assess convergent validity. CFA of a full measurement model was conducted in LISREL 8.80, where each item linked only to the construct that it was supposed to measure. The fit indices of the model reached the recommended values (Bollen, 1989; Hair, et al., 1995) with $\chi^{2} / \mathrm{df}<2$, Bentler-Bonett Normed Fit Index $=0.9$, Comparative Fit Index $(\mathrm{CFI})=0.92$, Joreskog-Sorbom's Fit Index $(\mathrm{GFI})=0.91$, and Root Mean-Square Error of Approximation $(\mathrm{RMSEA})=0.05$.

Convergent validity was first assessed by the significance of coefficient of each measurement item (Kaynak and Hartley, 2008). The standard factor loading of the items on the constructs is reported in APPENDIX A. The coefficients were greater than twice their standard error, which resulted in t-statistics significant at $\mathrm{p}<0.001$ and indicated high convergent validity (Anderson and Gerbing, 1988). Discriminant validity was evaluated by two steps. First, we used two-factor CFA models that related each possible pair of constructs, with the correlation between the two constructs first set freely and then constrained to one (Bagozzi, et al., 1991; Li, et al., 2005). The $\chi^{2}$ value for the unconstrained model was significantly lower than that of the constrained model. The results established discriminant validity among all the three constructs.

Reliability was assessed by Cronbach's alpha and composite reliability. All the constructs reached an acceptable Cronbach's alpha (Nunnally, 1978), being greater than 0.70 (see APPENDIX A). The value of composite reliability of all constructs exceeded the suggested threshold of 0.70 (Bagozzi and Yi, 1988). All the evidences supported good construct reliability. 


\section{Environmental Uncertainty}

An index composed of three variables is used to measure environmental uncertainty. The indicator variables (using a seven-point Likert scale) capture the changes in customer needs, demand, and competitive pressures (see APPENDIX B). The average of the three indicator variables was used to measure environmental uncertainty. This index allows for the possibility of the presence of more than one type of environmental uncertainty (Pagell and Krause, 1999). Higher values imply higher levels of environmental uncertainty. High and low levels for the environmental uncertainty are determined by the median value of the index.

\section{Organizational Flatness}

Organizations with more hierarchical levels have tighter or narrower spans of control and hence represents a more mechanistic structure; while fewer hierarchical levels allow for more flexible internal arrangements (Burns and Stalker, 1961; Daft, 2009). This study measures organizational structure with two indicators about the number of levels in the organization (see APPENDIX B). The two seven-point Likert scale items are adapted from existing literature (Aiken and Hage, 1966; Zanzi, 1987). The average of the scores of the items measures the organizational structure of the plant. Higher average scores imply a higher mechanistic structure, while lower scores indicate an organic structure. Median value of the index is used to classify organizations into flat or hierarchical structure.

\section{Organizational Strategy}

The strategic goal of low cost or differentiation is measured by four items: percent of sales spent on R\&D, percent of sales spent on marketing expenses, brand image, and product features. The four items loaded on a single factor, with factor loadings of $0.76,0.66,0.76$, and 0.72 respectively. The Cronbach's alpha value is 0.70 and the total variance explained is $53 \%$ (See APPENDIX B). A higher value of the factor score indicates a focus on differentiation, while a lower value indicates a focus on low cost.

\section{Operational Performance}

Previous research often used four dimensions to measure manufacturing performance: cost, quality, delivery, and flexibility. This study uses these same four dimensions and adapts the scales from previous research (Cleveland, et al., 1989; Klassen and Whybark, 1999). The measurement items for operational performance are given in the APPENDIX C. Overall the composite reliability for each scale exceeds 0.65 (Cost, 0.71; Quality, 0.66; Delivery, 0.76; Flexibility, 0.72), loads on a single factor, and explains more than $60 \%$ of the variance. TABLE 2 summarizes the data and gives the mean, standard deviation, and correlations for the constructs described above.

TABLE 2 MEANS, STANDARD DEVIATIONS, AND CORRELATIONS OF THE VARIABLES

\begin{tabular}{lccccccccc}
\hline & Mean & S.D. & 1 & 2 & 3 & 4 & 5 & 6 & 7 \\
1. Enactment of internal & 5.1 & .6 & 1 & & & & & & \\
stakeholders & & & & & & & & & \\
2. Enactment of suppliers & 5.2 & .5 & $.31^{* *}$ & 1 & & & & & \\
3. Enactment of customers & 5.4 & .5 & $.31^{* *}$ & $.43^{* *}$ & 1 & & & & \\
4. Organizational flatness & 4.4 & 1.1 & $.22^{* *}$ & .08 & $.34^{* *}$ & 1 & & & \\
5. Environmental uncertainty & 5.0 & .7 & .02 & .08 & $.13^{* *}$ & -.09 & 1 & & \\
6. Strategic goals & 3.4 & .5 & $.19^{* *}$ & $.19^{* *}$ & .09 & -.05 & -.04 & 1 & \\
7. Operational Performance & 3.7 & .5 & $.23^{* *}$ & $.25^{*}$ & $.27^{* *}$ & $.17^{*}$ & .04 & $.39^{* *}$ & 1 \\
\hline
\end{tabular}

**. Correlation is significant at the 0.01 level (2-tailed).

*. Correlation is significant at the 0.05 level (2-tailed). 


\section{ANALYSIS}

Based on the theoretical development, we classified the sample organizations into two groups, the fit group and the misfit group. Two scenarios are included in the fit group: when environmental uncertainty is high, organizations should use flat structure and differentiation strategy to better deal with the high uncertainty; while when environmental uncertainty is low, organizations should use a more hierarchical structure and low cost strategy in order to better control efficiency. In the misfit group, there are two subgroups: environment-organization misfit and structure-strategy misfit. Environment-organization misfit includes the scenarios that organizational structure and strategy are not matching the environmental uncertainty level the organization is facing. Structure-strategy misfit shows the scenarios that have inconsistence between organizational structure and organizational strategy. The combinations of environmental uncertainty, organizational structure, and organizational strategy within each group are listed in TABLE 3.

TABLE 3

GROUPS OF SAMPLE BASED ON ENVIRONMENT-ORGANIZATION AND STRUCTURE-STRATEGY FIT/MISFIT

\begin{tabular}{|c|c|c|c|c|c|c|c|}
\hline & & \multicolumn{2}{|c|}{$\begin{array}{l}\text { Environmental } \\
\text { uncertainty }\end{array}$} & \multicolumn{2}{|c|}{$\begin{array}{l}\text { Organizational } \\
\text { structure }\end{array}$} & \multicolumn{2}{|c|}{ Organizational strategy } \\
\hline & & High & Low & Flat & hierarchical & Differentiation & Low cost \\
\hline \multirow{2}{*}{$\begin{array}{l}\text { Fit (sample } \\
\text { size: } 35)\end{array}$} & Scenario 1 & $\sqrt{ }$ & & $\sqrt{ }$ & & $\sqrt{ }$ & \\
\hline & Scenario 2 & & $\sqrt{ }$ & & $\sqrt{ }$ & & $\sqrt{ }$ \\
\hline \multirow{2}{*}{$\begin{array}{l}\text { Environment- } \\
\text { organization } \\
\text { misfit (sample } \\
\text { size: 95) }\end{array}$} & Scenario 1 & $\sqrt{ }$ & & & $\sqrt{ }$ & & $\sqrt{ }$ \\
\hline & Scenario 2 & & $\sqrt{1}$ & $\sqrt{1}$ & & $\sqrt{ }$ & \\
\hline \multirow{4}{*}{$\begin{array}{l}\text { Structure- } \\
\text { strategy misfit } \\
\text { (sample size: } \\
108)\end{array}$} & Scenario 1 & $\sqrt{ }$ & & $\sqrt{ }$ & & & $\sqrt{ }$ \\
\hline & Scenario 2 & & $\sqrt{ }$ & $\sqrt{ }$ & & & $\sqrt{ }$ \\
\hline & Scenario 3 & $\sqrt{ }$ & & & $\sqrt{ }$ & $\sqrt{ }$ & \\
\hline & Scenario 4 & & $\sqrt{ }$ & & $\sqrt{ }$ & $\sqrt{ }$ & \\
\hline
\end{tabular}

A regression analysis is used to examine the relationship of external stakeholder enactment and internal stakeholder enactment on performance. We use the interaction term of external enactment* Environment-organization misfit, internal enactment * Environment-organization misfit, internal enactment * Structure-strategy misfit, and external enactment* Structure-strategy misfit to check the interaction effects of enactment and misfit on performance. The analysis includes industry type and country as the control variables. The regression function has two dummy variables for the three industry types. In addition, the regression model has seven dummy variables to measure the eight countries. The regression model follows:

Operational Performance $=\beta_{0}+\beta_{1}$ Industry $_{1}+\beta_{2}$ Industry $_{2}+\beta_{3}$ Country $_{1}+\beta_{4}$ Country $_{2}+\beta_{5}$ Country $_{3}+\beta_{6}$ Country $_{4}+\beta_{7}$ Country $_{5}+\beta_{8}$ Country $_{6}+\beta_{9}$ Country $_{7}+\beta_{10}$ External enactment $+\beta_{11}$ Internal enactment + $\beta_{12}$ External enactment $*$ Environment-organization misfit $+\beta_{13}$ Internal enactment $*$ Environmentorganization misfit $+\beta_{14}$ External enactment $*$ Structure-organization misfit $+\beta_{15}$ Internal enactment $*$ Structure-organization misfit

TABLE 4 gives the regression analysis. The analysis did not show any problems with the assumptions of regression analysis (e.g. normality and multicollinearity - all VIF's ranged from 1 to 3). 
TABLE 4

\section{REGRESSION RESULTS WITHIN THE FIT AND MISFIT GROUPS}

\begin{tabular}{lll}
\hline & \multicolumn{2}{l}{$\begin{array}{l}\text { Dependent variable: } \\
\text { Operational performance }\end{array}$} \\
\hline & $\begin{array}{l}\text { Fit } \\
(\mathrm{n}=35)\end{array}$ & $\begin{array}{l}\text { Misfit } \\
(\mathrm{n}=203)\end{array}$ \\
Industry ${ }_{\text {Machinery }}$ & -.090 & .118 \\
Industry Electronics & .246 & .019 \\
Country1 & -.620 & $-.239^{* *}$ \\
Country2 & -.200 & -.099 \\
Country3 & -.510 & -.025 \\
Country4 & -.551 & -.060 \\
Country5 & -.552 & -.093 \\
Country6 & -.513 & -.006 \\
Country7 & -.025 & -.161 \\
External enactment & .03 & \\
Internal enactment & .09 & $.222^{* *}$ \\
External enactment * Environment-organization misfit & & .108 \\
Internal enactment * Environment-organization misfit & & $.218^{* *}$ \\
External enactment * Structure-strategy misfit & & $.171^{*}$ \\
Internal enactment * Structure-strategy misfit & & .23 \\
R-Square & .41 & $<.001$ \\
P-value of overall model & .43 & \\
\hline ** P $<0.05$ & & \\
$*$ P $<0.01$ & & \\
& & \\
\hline
\end{tabular}

\section{Results}

In line with our Hypothesis 1 we find that, when there exists fit among environment, structure, and strategic goals, enactment of internal stakeholders and enactment of external stakeholders do not significantly influence performance. However, when there is misfit of the three factors, enactment matters. We find significant support for both Hypothesis 2 and 3 that predict such enactment buffering effects on performance in cases of misfit. Enactment of internal stakeholders does not buffer the environment-organization misfits but it buffers the within organizational misfit, which is the misfit between the organizational structure and strategic goals.

In addition, we find that enactment of external stakeholders buffers the misfit of both environmentalorganizational and organizational misfits (structure and strategy misfit), which is more than what we hypothesized. Enactment of external stakeholders such as suppliers and customers shows more compensating power and can buffer both types of misfit.

\section{DISCUSSION}

The questions of organizational and environmental fit have long been part of the strategic management literature. In this paper we offer empirical evidence for buffering effects of enactment of stakeholders. We investigated the influence on performance of enactment of internal stakeholders as well as external stakeholders. And the empirical evidence is from a sample of 238 plants across eight countries.

We find that in cases of fit, enactment of stakeholders does not seem performance relevant. However, in case of misfit enactment of stakeholders does become performance relevant. Based on our results we 
can argue that environment-organization misfits can be buffered by enactment of external stakeholders such as suppliers and customers, where as internal misfits of structure and strategy can be buffered by enactment of internal stakeholders such as employees as well as the enactment of external stakeholders. Previous research has shown that configurational misfits between environmental uncertainty, strategy, and structure are only influencing performance to a certain degree, and our research results elucidate the puzzling findings and provide explanations from the stakeholder enactment perspective.

This paper thus contributes to theory in a variety of ways. First, we developed our theory framework by employing three separated yet connected theoretical perspectives, which are contingency theory, configurational theory, and loosing coupling and stakeholder management. Our hope is to draw on the richness of contingency theory and configurational perspectives and connect them through loose coupling theory to explore potential reasons why results regarding fit and misfit are unclear. While a majority of scholars argues that fit is what management should work towards, we wish to find out particularly why accumulated misfit does not incur the predicted performance reductions. The three theoretical lens allowed us to investigate the misfittest and performance implications in a much more comprehensive way. By integrating three theoretical perspectives, we provided a fresh look at the research questions and provided innovative yet relevant conclusions. This also echoes the call of Van de Ven and colleages (2013) that more scholars should "return to the frontier of organization science by reopening the study of contingency theory of organizational and institutional designs" (2013, P. 394).

Second, we develop a framework that explains buffering effects of enactment of stakeholders in situations of organizational and environmental misfit. We take into consideration of two different types of misfit: the environment-organization misfit and the structure-strategy misfit. Previous research does not have a conclusive observation of how the misfit influences performance and when misfit matters. By separating the two different types of misfits, this study allows us to investigate the individual effect of enactment on different types of misfits. This could help to answer the questions such as which type of misfit could be buffered by internal or external enactment.

Third, by examining a large sample of manufacturing organizations, we confirm our hypothesis according to which enactment of external and internal stakeholders differently affect performance in cases of misfit. We specifically find that enactment of internal stakeholders is performance relevant when strategy and structure misfit exists, and that enactment of external stakeholders is performance relevant when environmental-organizational misfit or structure-strategy misfit exists. The empirical evidence of compensating effect of internal and external enactment contributes significantly to current literature with the majority of scholars argues that fit is what management should focus and work towards.

The results also have significant managerial implications. Instead of focusing on fittest, this study signifies the importance of managing the organizational and environmental misfit by introducing more enactment of internal and external stakeholders. When there exists fit between environment, strategy, and structure, enactment does not contribute significantly to performance. However, when misfit happens, the importance of enactment has been proved by our empirical results. This provides managers insights on how to improve performance through getting more enactment of employees, customers, and suppliers. Practitioners could use our research insights to investigate the fitting situation of their organizations and furthermore to implement our research results and use internal enactment and external enactment to compensate the performance disadvantage if misfit happens.

It is hoped that this study provides valuable insights into both theoretical and empirical relationships between enactment, environmental misfit, and organizational misfit. 


\section{REFERENCES}

Aiken, J., \& Hage, M. (1966). Organizational alienation: A comparative analysis. American Sociological Review, 31, 497-507.

Anderson, J. C., \& Gerbing, D. W. (1988). Structural eqation modeling in practice: a review and recommended two-step approach. Psychological Bulletin, 103(2), 411-423.

Bagozzi, R. P., Yi, Y., \& Phillips, L. M. (1991). Assessing construct validity in organizational research. Administrative Science Quarterly, 36(3), 421-458.

Bagozzi, R. P., \& Yi, Y. (1988). On the evaluation of structural equation models. Journal of Academy of Marketing Science, 16, 74-94.

Baird, L., \& Meshoulam, I. (1988). Managing two fits of strategic human resource management. Academy of Management Review, 13(1), 116-128.

Beekun, R. I., \& Glick, W. H. (2001). Organization structure from a loose coupling perspective: A multidimensional approach. Decision Sciences, 32(2), 227-250.

Bollen, K. A. (1989). Structural Equaltions with Latent Variables. New York, NY: John Wiley \& Sons.

Burns, T. \& Stalker, G. M. (1961). Mechanistic and organic systems, Classics of organizational theory. Pacific, CA: Brooks/Cole.

Burton, R. M., \& Obel, B. (1998). The Environment. In Strategic Organizational Diagnosis and Design (pp. 165-210). Springer US.

Burton, R. M., \& Obel, B. (2004). Strategic organizational diagnosis and design: The dynamics of fit (Vol. 4). Springer Science \& Business Media.

Burton, R. M., \& Lauridsen, J., Obel, B. (2002). Return on assets loss from situational and contingency misfits. Management Science, 48(11), 1461-1485.

Cleveland, G., Schroeder, R. G., \& Anderson, J. C. (1989). A theory of production competence. Decision Sciences, 20(4), 655-668.

Daft, R. L. (2009). Organization theory and design. South-Western Pub.

Danneels, E. (2003). Tight-loose coupling with customers: the enactment of customer orientation. Strategic Management Journal, 24(6), 559-576.

Danneels, E. (2008). Organizational antecedents of second order competences. Strategic Management Journal, 29(5), 519-543.

Haakonsson, D., Burton, R. M., Obel, B. \& Lauridsen, J. (2008). How failure to align organizational climate and leadership style affects performance. Management Decision, 46(3), 406-432.

Donaldson, L. (2001). The contingency theory of organizations.: Sage Publications, Incorporated.

Doty, D. H., Glick, W. H., \& Huber, G. P. (1993). Fit, equifinality, and organizational effectiveness: A test of two configurational theories. Academy of Management Journal, 1196-1250.

Eisenhardt, K. M., \& Brown, S. L. (1998). Competing on the edge: Strategy as structured chaos. Long Range Planning, 31(5), 786-789.

Freeman, R. E. (2010). Strategic management: A stakeholder approach. Cambridge University Press.

Freeman, R. E., Wicks, A. C., \& Parmar, B. (2004) Stakeholder theory and "the corporate objective revisited”. Organization Science, 15(3), 364-369.

Gresov, C. (1989). Exploring fit and misfit with multiple contingencies. Administrative Science Quarterly, 431-453.

Gresov, C., \& Drazin, R. (1997). Equifinality: Functional equivalence in organization design. Academy of Management Review, 22(2), 403-428.

Hair, J. F., Anderson, R. E., Tatham, R. L., \& Black, W. C. (1995). Multivariate Data Analysis (4th ed.). Englewood Cliffs, NJ: Prentice Hall.

Kaynak, H., \& Hartley, J. L. (2006). Using replication research for just-in-time purchasing construct development. Journal of Operations Management, 24, 868-892.

Kaynak, H., \& Hartley, J. L. (2008). A replication and extension of quality management into the supply chain. Journal of Operations Management, 26, 468-489. 
Ketchen, D. J., Combs, J. G., Russell, C. J., Shook, C., Dean, M. A., Runge, J. \& Lamoureux, S. (1997). Organizational configurations and performance: A meta-analysis. Academy of Management Journal, 40(1), 223-240

Klassen, R. D., \& Whybark, D. C. (1999). The impact of environmental technologies on manufacturing performance. Academy of Management Journal, 42(6), 599-615.

Lawrence, P. R., \& Lorsch, J. W. (1967). Differentiation and integration in complex organizations. Administrative Science Quarterly, 1-47.

Lee, J., \& Miller, D. (1996). Strategy, environment and performance in two technological contexts: contingency theory in Korea. Organization Studies, 17(5), 729-750.

Li, S., Rao, S. S., Ragu-Nathan, T. S., \& Ragu-Nathan, B. (2005). Development and validation of a measurement instrument for studying supply chain management practices. Journal of Operations Management, 23(6), 618-641.

Meyer, A. D., Tsui, A. S., \& Hinings, C. R. (1993). Configurational approaches to organizational analysis. Academy of Management Journal, 36(6), 1175-1195.

Miles, R. E., Snow, C. C., Meyer, A. D., \& Coleman Jr, H. J. (1978). Organizational strategy, structure, and process. Academy of Management Review, 546-562.

Miller, D. (1992). Environmental fit versus internal fit. Organization science, 3(2), 159-17.

Miller, D. (2006). Configurations of strategy and structure: Towards a synthesis. Strategic Management Journal, 7(3), 233-249.

Nadler, D. A., \& Tushman, M. L. (1980). A model for diagnosing organizational behavior. Organizational Dynamics, 9(2), 35-51.

Nadler, D., \& Tushman, M. L. (1988). Strategic organization design: Concepts, tools \& processes. Glenview, Ill: Scott, Foresman.

Naman, J. L., \& Slevin, D. P. (1993). Entrepreneurship and the concept of fit: A model and empirical tests. Strategic Management Journal, 14(2), 137-153.

Nunnally, J. C. (1978) Psychometric Theory (2 ed.). New York: McGraw-Hill.

Pagell, M., \& Krause, D. R. (1999). A multiple-method study of environmental uncertainty and manufacturing flexibility. Journal of Operations Management, 17(3), 307-325.

Orton, J. D., \& Weick, K. E. (1990). Loosely coupled systems: A reconceptualization. Academy of Management Review, 15(2), 203-223.

Payne, G. T. (2006). Examining configurations and firm performance in a suboptimal equifinality context. Organization Science, 17(6), 756-770.

Pérez-Nordtvedt, L., Payne, G. T., Short, J. C., \& Kedia, B. L. (2008). An entrainment-based model of temporal organizational fit, misfit, and performance. Organization Science, 19(5), 785-801.

Sanchez, R. (1995). Strategic flexibility in product competition. Strategic Management Journal, 16(S1), $135-159$.

Van de Ven, A. H., Ganco, M., \& Hinings, C. R. (2013). Returning to the frontier of contingency theory of organizational and institutional designs. The Academy of Management Annals, 7(1), 393-440.

Weick, K. E. (1979). The social psychology of organizing (Topics in social psychology series).

Weick, K. E. (1985). The significance of corporate culture. Organizational Culture, 381-389.

Wicks, A. C., Berman, S. L., \& Jones, T. M. (1999) The structure of optimal trust: Moral and strategic implications. Academy of Management Review, 99-116.

Wiklund, J., \& Shepherd, D. (2005). Entrepreneurial orientation and small business performance: a configurational approach. Journal of Business Venturing, 20(1), 71-91.

Wright, P. M., \& Snell, S. A. (1998). Toward a unifying framework for exploring fit and flexibility in strategic human resource management. Academy of Management Review, 23(4), 756-772.

Zajac, E. J., Kraatz, M. S., \& Bresser, R. K. (2000). Modeling the dynamics of strategic fit: A normative approach to strategic change. Strategic Management Journal, 21(4), 429-453.

Zanzi, A. (1987). How Organic is your Organization? Determinants of Organic/Mechanistic Tendencies in a Public Accounting Firm. Journal of Management Studies, 24(2), 125-142. 


\section{APPENDIX A MEASUREMENT ITEMS FOR ENACTMENT OF EXTERNAL AND INTERNAL STAKEHOLDERS}

Respondents were asked to indicate the extent to which they agree or disagree with each of these statements about their plant and organization.

1: Strongly disagree, 4: Neutral, 7: Strongly agree

Enactment of internal stakeholders (Cronbach alpha $=.87$ )

Factor Loading

Management takes all product and process improvement

suggestions seriously.

We are encouraged to make suggestions for improving

performance at this plant.

Management tells us why our suggestions are implemented or

not used.

Many useful suggestions are implemented at this plant.

Enactment of external stakeholders

Enactment of suppliers (Cronbach alpha $=.85$ )

We maintain cooperative relationships with our suppliers. $\quad .736$

We help our suppliers to improve their quality. $\quad .766$

We maintain close communications with suppliers about $\quad .800$

quality considerations and design changes.

$\begin{array}{ll}\text { Our key suppliers provide input into our product development } & .739\end{array}$

projects.

Enactment of customers (Cronbach alpha $=.81$ )

We work as a partner with our customers.

We frequently are in close contact with our customers. $\quad .800$

Our customers give us feedback on our quality and delivery $\quad .805$

performance.

Our customers are actively involved in our product design $\quad .647$

process.

$\begin{array}{ll}\text { We strive to be highly responsive to our customers' needs. } & .769\end{array}$

We regularly survey our customers' needs. 


\section{APPENDIX B MEASUREMENT ITEMS FOR ORGANIZATIONAL STRUCTURE, ENVIRONMENTAL UNCERTAINTY, AND STRATEGIC GOALS}

Indicators for organizational flatness (higher means less flat)

There are many levels between the lowest level in the organization and top management.

Our organizational chart has many levels.

Indicators for environmental uncertainty (higher means more uncertain)

The needs and wants of our customers are changing very fast.

The demand for our plant's products is unstable and unpredictable.

Our competitive pressures are extremely high.

Measurement items-strategic goals

Respondents were asked to position their emphases of the following items relative to those of their leading competitors:

1: Significantly lower, 5: Significantly higher

Strategic goals $($ Cronbach alpha $=.81)$ :

Percent of sales spent on R\&D

Factor loading

Percent of sales spent on marketing expenses $\quad 0.66$

Brand image $\quad 0.76$

$\begin{array}{ll}\text { Product features } & 0.72\end{array}$

\section{APPENDIX C MEASUREMENT ITEMS FOR OPERATIONAL PERFORMANCE}

Please circle the number which indicates your opinion about how your plant compares to its competition in your industry, on a global basis.

Poor or low end of the industry, 3. Average, 5. Superior or better than average

Cost

$\begin{array}{ll}\text { Unit cost of manufacturing } & .703\end{array}$

$\begin{array}{ll}\text { Inventory turnover } & .847\end{array}$

Cycle time (from raw materials to delivery) $\quad .846$

Quality

Conformance to product specifications $\quad .865$

$\begin{array}{ll}\text { Product capability and performance } & .865\end{array}$

Delivery

On time delivery performance $\quad .896$

$\begin{array}{ll}\text { Fast delivery } & .896\end{array}$

Flexibility

Flexibility to change product mix $\quad .884$

Flexibility to change volume $\quad .884$ 